\title{
3. A Contribution to the History of Eocene Siluroid
} Fishes. By E. T. Newton, F.G.S., F.Z.S.

[Received March 14, 1889.]

\section{(Plate XXI.)}

The pectnral and dorsal spines of Siluroid fishes from Bracklesham, which were referred to the genus Silurus by Dixon $\left(2^{1}\right)$, have recently been studied by Mr. A. Smith Woodward (12), who has shown the improbability of these remains belonging to the temperate genus Silurus and the close relationship existing between them and the widely distributed tropical genus Arius. In addition to the spines and pectoral arch, named by Dixon Silurus egertoni, Mr. S. Woodward has called attention to several other specimens, some from the Upper Eocene of Barton, preserved with the types in the British Museum, among which are bones of the skull and notably some large and characteristic supraoccipitals, one of which he figures; these he also refers to Arius egertoni. Some smaller spines with a double curvature, from Barton, he places in a new species, Arius (?) bartonensis.

The Museum of Practical Geology now possesses the greater part of a skull from the Eocene beds of Barton (Plate XXI. figs. 1, 2,3), which confirms in a most satisfactory manner Mr. S. Woodward's reference of the Eocene Siluroids to the genus Arius. The skull is somewhat crushed, but the bones are still in position, and by careful manipulation both the upper and under surfaces have been exposed. The ethmoid, prefrontals, and part of the supraoccipital are wanting, and on the right side the temporal region is broken, but on the lett only one of the temporal plates is lost.

All the bones of the upper surface, which are preserred, are ornamentfd with rounded granules, and these in nearly all cases radiate from an ill-defined centre towards the margins of the bone. No distinct sutures can be seen, but the ornamentation being less strongly marked towards the edges of the bones, the boundaries can be fairly well made out; the dark lines in the figure indicate these boundaries, which agree in the main with the positions of the sutures in the recent specimen with which it has been compared.

The frontals $(f r$.$) occupy the anterior part of the specimen; they$ are narrow posteriorly and meet each other in the middle line for about half their length. The median point of the supraoccipital projects for a short distance between their hinder extremities. Anteriorly a wide and deep depression occupies the median portion of the frontals, and at the bottom of this depression a long cleft separates their inner margins. Each bone is in front divided into two parts, the outer of them no doubt joined the prefrontal and the inner the ethmoid, as in the recent Arius.

Behind and on the outer side, each frontal joins a plate (sp.ot.)

1 These numbers refer to a list of works given p. 206. 
which is also in relation with the supraoccipital (s.o.) and with a much smaller bone ( $p t . o t$.) which lies behind it. This plate (sp.ot.) has on its under surface a deep depression, which evidently formed the attachment for the hyomandibular; the depression is not, however, quite confined to this plate, but seems to extend for a short distance on to the smaller bone which lies behind it. These two bones, therefore, which have combined to support the hyomandibular, are regarded as the sphenotic (postfrontal) and the pterotic (squamosal).

The last-named bone comes into relation with the supraoccipital on the inner side and has behind it two elements, the outer of which is evidently the post-temporal (pt.tem.) and the inner one (pa.) is either the parietal or epiotic. Another bone which is found behind these in the recent Arius has evidently been lost in this fossil. The post-temporal ( $p t . t e m$.) has a peculiar and characteristic structure. On the upper surface of the skull it presents a flattened tuberculated plate, which, a comparison with the recent Arius gagorides shows, is composed of two parts - an anterior, united with the pterotic, and a hinder one attached to the bone directly on its inner side, the parietal (or epiotic), and extending as far as the supraoccipital. The post-temporal must also have been in close relation with the bone behind it, which has been lost; but the smooth surface now exposed does not indicate a close attachment. The outer extremity of the post-temporal has a very distinct socket for the upper part of the supraclavicular, and from below this a strong bar of bone passes downwards and inwards quite to the base of the skull, to which it has been firmly attached. There is a thin plate of bone $(x)$ behind this bar, which seems to have been separated from it by the crushing of the skull, that passes backwards and inwards, seemingly to join the broad thin horizontal plate formed by the transverse processes of the vertebræ; indeed, it may be that this is a part of the transverse process, extending forward to join the post-temporal.

The hinder part of the supraoccipital is wanting, but the front part is preserved and is somewhat shield-shaped, having its margins on each side indented by a series of curves where it is united with the frontal, sphenotic, pterotic, and parietal. The hindermost temporal plate, now wanting, was doubtless also in contact with the supraoccipital.

The base of the skull is much crushed, but it seems quite certain that the brain-cavity was completely enclosed by bony walls. The buttress-like supports of the post-temporal bones are striking features of this region. Just in front of the left buttress may be seen the remains of an inflated bulla, which lodged one of the large otoliths, and still further forward there is on each side a depression for the attachment of the hyomandibular $(\mathrm{hm}$.). In front of this again is another pair of elongated depressions, evidently the ethmoid attachments for the prefrontals (fig. 2, eth.). The most anterior part of the base, in its present condition, is formed by a fan-shaped mass, which is apparently in part the vomer and in part the ethmoid.

'Three or four of the anterior vertebræ are firmly united to each 
other, so that the centra appear as one bone closely united to the basioccipital, and at their point of union with the latter bone there is a strong downwardly directed process.

The Arius skull most closely resembling this fossil is one in the British Museum, which Dr. Günther assures me is almost certainly Arius gagorides. The correspondence between this and the fossil is so close as to leave no doubt as to their generic identity, and the following comparisons refer to this specimen. I have to acknowledge my indebtedness to Dr. Günther, who on this, as on many other occasions, has spared no trouble in order to facilitate my examination of the specimens under his charge, thereby enabling me to settle the affinities of this fossil fish in a manner which would not otherwise have been possible.

The frontals of $A$. gagorides (fig. 8, $f r$.) differ from those of the Barton fossil in having the median cleft extended further backwards, and their hinder ends are proportionately wider. The latter character is in relation to the form of the sphenotics, which are relatively narrower at their hinder part than is the case in the fossil.

In ordinary bony fishes the post-temporal is connected with the skull by two processes, one of which is attached to the pterotic (squamosal) and the other to the epiotic; but the post-temporal of A. gagorides has in addition to these a third attachment by means of a long bar extending from its under surface to the base of the skull (fig. 9), and in addition to this there is a thin plate of bone, which may be a process of the post-temporal, extending under the epiotic to the transverse process of the vertebræ. The two upper processes of the post-temporal are ornamented on their upper surface with tubercles, and between them and the pterotic an opening is left which seems to vary in extent in different specimens. The bone to which the hinder of these processes is attached appears from its connections and relations to the auditory region to be the epiotic; but it may be the parietal. If the latter be the correct interpretation, then the ossicle behind it may be the epiotic; and the hinder process of the post-temporal certainly reaches thus far. On the other hand, if the parietal be absent and this bone be the epiotic, then the hinder plate will probably be a supernumerary temporal plate, wedged in between the wide hinder moiety of the supraoccipital and the epiotic.

The post-temporal bone of Arius gagorides has the same structure and relations as that described in the Barton skull; but the opening left between its two upper processes is not seen in the fussil. This feature, however, varies even in the recent species, and in the fossil the two processes evidently have joined and obliterated the space.

The pterotic and parietal elements are larger than in the fossil, the last-named bone reaching to the margin of the bony cephalic shield, while in the fossil it seems probable that the epiotic and post-temporal bones excluded it from the margin.

The supraoccipital of $\boldsymbol{A}$. gagorides is an elongated bone constricted in the middle, the portion in front of the constriction corresponding with the part preserved in the fossil. In the main 
the indentations of the margin are alike in the two forms, but the supraoccipital of the fossil is evidently a shorter and wider bone, and it is uncertain whether it was constricted in the middle or not. The supraoccipital of $A$. egertoni is only slightly constricted, and it may be that the Barton skull, here described, more resembled that species.

Several of the anterior vertebræ of A. gagorides are united to form one mass, in a manner precisely similar to that which obtains in the fossil.

The differences above noted show clearly that the recent and fossil forms are specifically distinct, while at the same time the resemblances are sufficiently important to prevent a generic separation; but there is still some additional evidence which supports this decision in an unexpected manner.

While clearing away the matrix from the right side of the fossil skull, where it is broken near the back, I was fortunate enough to find one of the otoliths in place, and this, when extracted, proved to be of a remarkable form (figs. $3, a, b, c$ ), and quite unlike the otolith of any fish with which I was acquainted.

When found, this otolith had the more pointed end directed backwards and outwards, with the smooth surface upwards; and as it seemed to be in its natural cavity, for the present this is regarded as its proper position; but seeing that the otolith of the opposite side is not in its place, and that in the diried skull of the recent species they are loose in the brain-cavity, this may not be correct.

The otolith is proportionately large and thick, its upper surface $(a)$ is smooth and convex, while its lower surface $(b)$ is rugose and much more convex. At first sight there appears to be no sulcus acusticus, but probabiy it is represented by the sinuous groove on the lower surface which passes from the hinder pointed end to the opposite extremity, that is between the two stars in figure $3 b$. The rugosity of the under surface is due to a number of concentric striations, or lines of growth, crossed by several radiating ridges which are stronger on the inner than on the outer portion. One of the radiating ridges is especially strong, and forms a prominent angle where it reaches the inner margin, towards the front of the otolith (fig. $3 b, x$ ). The pointed extremity is seen to be notched, a slight groove extending from this both on the upper and lower surfaces (figs. $3 a, b$ ). From this bifid point a shallow groove extends along the outer margin, becoming a mere line towards the front; it is seen in an upper view (fig. $3 a$ ), and is separated from the smooth upper surface by a fine but distinct raised line.

A similar otolith to this is figured by Herr E. Koken, from the O'igocene of Headon Hill, Isle of Wight (6), who, having no clue to its affinities, called it Otolithus (incertce sedis) crassus.

The close relationship between the recent Arius gagorides and the Barton fossil skull made it particularly desirable to see whether the otoliths would show a corresponding resemblance, and Dr. Günther very kindly had the otoliths taken out of the skull with which the above comparisons had been made. One of these otoliths is repre- 
sented by figure 10, and it will be seen that all the points mentioned as characteristic of the fossil otolith are repeated in this, and it is only in outline that there is any real difference. The projection of the inner margin marked $x$ (fig. $10 b$ ) is in a depression and does not form a prominent angle as in the fossil (fig. $3 b$ ), and the swelling of the outer margin $(y)$ is, in $A$. gagorides, placed further backwards than in the fossil.

Unfortunately, the otoliths of nearly allied recent species or genera are not available for comparison, and consequently we know nothing of their specific differences. In the collection of Fish otoliths preserved in the Hunterian Museum of the Royal College of Surgeons there are a few belonging to Siluroids, but none of them to genera nearly allied to Arius, and they all differ widely from the otolith of Arius gagorides.

The series of otoliths from the Upper Eocene of Barton, preserved in the British Museum, includes many which agree with $A$. gagorides in these main characters which seem to me to be generic, and these, therefore, I also refer to the genus Arius. Besides differences of size, which in part no doubt are due to age, these otoliths present several distinct forms, which I believe will be found to represent at least three species, in addition to the skull above described. The largest of these (fig. 4) is a little longer and more regularly oval than that found in the Barton skull; its lower surface is also flatter, and its upper surface is raised into an almost conical boss.

The second form to be noticed (fig. 5) is smaller, flatter, and more rounded in outline, having the hinder point only slightly produced.

The third form (fig. 6) is likewise flat and about the same size as the one last noticed; in outline, however, it more resembles that of A. gagorides, but the swelling of the outer side $(y)$ is not thrown so much backwards as in that species.

There is still another form of Arius otolith to which I should like to call attention. Among the fossils brought from Madagascar by the Rev. R. Baron, and noticed in his paper read before the Geological Society (Mar. 6, 1889), were some small otoliths (fig. 7) which he had collected in the village of Ankoala, where they occurred in some numbers scattered over the surface of the ground. These otoliths bear such a close resemblance to some of those from the Eocene beds of Barton, that they not unnaturally led to the supposition that they also were of Eocene age; but both these forms are referable to the living genus Arius, which is a widely distributed tropical form, and it seems very probable, therefore, that the Ankoala specimens may prove to be of much more recent origin, and the peculiar conditions under which they were found seem to point to their belonging to a living species.

We have now to consider the relation which the Barton skull and the otoliths above described bear to the specimens referred to Arius egertoni and to $A$. ? bartonensis; and before doing so I may say that I quite agree with Mr. Smith Woodẉard's reference of the cephalic plates from Brackiesham to the species $A$. egertoni; for their 
ornamentation is peculiar and exactly corresponds with that found on the pectoral plate originally described by Dixon. The tubercles on all these specimens are sharp, conical, and more or less connected together by ridges which give a reticulated appearance to the plates when closely examined. Spines which cannot be distinguished from those of $A$. egertoni are found at Barton; but the skull above described differs from A. egertoni in several particulars, although it is only the supraoccipital bone which is available for comparison. This bone, so far as it is preserved, has a different form from that of $A$. egertoni, being proportionally wider and with less deeply grooved mucus-canals. The ornamentation of the bones, likewise, is of another character; the tubercles are more numerous, more rounded, and with little or no indication of the reticular structure between them ; moreover, they have a greater tendency to run together in radiating lines, and to become less distinct towards the margins of the bones. It will be obvious that this skull cannot be referred to $A$. egertoni, and there seems no good grounds for referring it to A. ? bartonensis, which is a smaller form and not certainly belonging to the genus Arius. On the other hand, there can be no question as to the otolith found in this skull being specifically identical with the one figured and described by Herr E. Koken (6) as Otolithus (incertce sedis) crassus, and this specific name must therefore be adopted for our specimen, which will benceforth be known as Arius crassus. Should the spines called $A$. bartonensis prove eventually to belong to the same species, the name of $A$.crassus having priority will have to be retained, although it may be a less appropriate cognomen. According to Herr Koken this form of otolith has been found at Headon Hill, Isle of Wight, and also in Oligocene strata at Lattorf, Cassel, Westeregeln, and Waldböckelheim, in Germany. The specimen from the Miocene of Tortonese, referred to by Herr Koken as possibly belonging to this species, which is figured by Dr. Sismonda (Mem. Accad. Sci. Torino, 1849, ser. 2, vol. x. pl. 2. fig. 71), does not seem to me to belong to the genus Arius.

It is quite likely that one or other of the three forms of otoliths from Barton may belong to $A$. egertoni or $A$. bartonensis; but it is likely to be long before the means of correlating them will be found, and I have thought it best to distinguish them provisionally as Arius (otolithus) sp. A (fig. 4), Arius (otolithus) sp. B (fig. 5), and Arius (otolithus) sp. C (fig. 6).

Should the otolith from Ankoala, Madagascar (fig. 7), prove to belong to an undescribed species, I wou!d suggest that it be named after the gentleman who brought it to this country, Arius baroni.

\section{Works that may be consulted on Fossil Siluroid Fishes.}

1. Cope, E. D.-The Vertebrata of the Tertiary Formations of the West. Rep. U.S. Geol. Surv. vol. iii. Book i. p. 62 (1884).

2. Dixon, F.-Geology and Fossils of Sussex. 1st edit. 1850, p. $204 ;$ 2nd edit. 1878 , p. 244.

3. Günther, A.- "Contributions to our Knowledge of the Fish 
Fauna of the Tertiary Deposits of the Highlands of Padung, Sumatra." Geol. Mag. dec. 2, vol. iii. p. 433 (18;6).

4. HeскеL, J. J.-Beiträge zur Kenntniss der fossilen Fische Oesterreichs." Sitzungsb. k. Akad. Wiss. Wien, 1849, p. 19, and Denkschr. vol. i. p. 213 (1850).

5. Koenig, C.-Icones Fossilium Sectiles, pl. viii. fig. 91 (1825).

6. KокеN, E.-“ Ueber Fisch-Otolithen \&c." Zeitschr. deutsch. geol. Gesell. vol. xxxvi. p. 559, pl. xii. fig. 13 (1884).

7. Le Hon.-Préliminaires d'un Mémoire sur les Poissons Tertiaires de Belgique, p. 15 (1871). [Notes occurrence only.]

8. LEIDY, J.-Contributions to the extinct Vertebrate Fauna of the Western Territories. Rep. U.S. Geol. Surv. 1873, p. 193.

9. Lydekker, R.-Siwalic Crocodilia \&c. and Tertiary Fishes. Palæont. Indica, ser. x. vol. iii. p. 246 (1886).

10. Marck, W. von DER. - "Neue Fische und Krebse aus der Kreide von Westphalien.” Palæontogr. rol. xv. p. 276 (1868); and vol. xxxi. p. 248 (1885).

11. Sauvage, H. E., in C. Depéret's “Description Géologique du Bassin Tertiaire du Roussillon.” Ann. d. Sci. Géol. vol. xvii. p. 223 (1885).

12. Woodward, A. Sмiтh._- "On some remains of Siluroid Fishes from British Eocene Formations.” Geol. Mag. dec. 3, vol. iv. p. 303 (1887).

13. Woodward, A. Sмith.- "On Bucklandium diluvii, Koenig; a Siluroid fish from the London Clay of Sheppey." Brit. Assoc. Rep. 1888, and Ann. \& Mag. Nat. Hist. ser. 6, vol. ii. p. 355 (1888).

14. Zittel, Karl A.-Handbuch der Palaeontologie, vol. iii. p. 360 (1888).

\section{EXPLANATION OF PLATE XXI.}

All the figures are natural size except numbers 8 and 9 , which are reduced one third.

Fig. 1. Arius crassus, Koken. Skull from the Upper Eocene of Barton, im the Museum of Practical Geology, upper surface.

2. Same specimen, under surface.

3. Otolith from right side of same specimen : $a$, upper surface; $b$, lower surface; $c$, side view.

4. Arius species A. Otolith (left?) from Upper Eocene of Barton, in the British Museum.

5. Arius species B. Otolith (right?); ditto, ditto.

6. Arius species C. Otolith (right?); ditto, ditto.

7. Arius baroni, n. sp. Otolith (right?) from Ankoala, Madagasear, in the Baron Collection, British Museum.

8. Arius gagorides, Cuv. \& Val. (living species, from Calcutta). Upper surface of left half of a skull $8 \frac{1}{2}$ inches long, two thirds natural size. In the British Museum.

9. Same specimen, lower surface.

10. Otolith (right?) from same specimen, natural size; letters as in figure 3 .

s.o., supraoccipital ; ep.ot., epiotic (?) ; pa., parietal (?) ; pt.tem., post temporal; pt.ot., pterotic; sp.ot., sphenotic ; fr., frontal; $p r . f r$., prefrontal ; eth., ethmoid; tr.pr., transverse process of vertebra; $h m$., articulation for hyomandibular. 


\section{$2 \mathrm{BHL}$ Biodiversity Heritage Library}

Newton, Edwin Tulley. 1889. "A Contribution to the History of Eocene Siluroid Fishes." Proceedings of the Zoological Society of London 1889, 201-207. https://doi.org/10.1111/j.1469-7998.1889.tb06771.x.

View This Item Online: https://www.biodiversitylibrary.org/item/96894

DOI: https://doi.org/10.1111/j.1469-7998.1889.tb06771.x

Permalink: https://www.biodiversitylibrary.org/partpdf/72912

\section{Holding Institution}

Natural History Museum Library, London

\section{Sponsored by}

Natural History Museum Library, London

\section{Copyright \& Reuse}

Copyright Status: Public domain. The BHL considers that this work is no longer under copyright protection.

This document was created from content at the Biodiversity Heritage Library, the world's largest open access digital library for biodiversity literature and archives. Visit BHL at https://www.biodiversitylibrary.org. 